\title{
Diskursus Etika Aristoteles dalam Islam
}

\author{
Ahmad Habibi \\ IAIN Syaikh Abdurrahman Siddik Bangka Belitung, Indonesia \\ habibulmalik1@gmail.com
}

\begin{abstract}
Ethics has always been an interesting subject to be discussed. It is not only its theoretic culture that contains rich values, but Ethics is also an applied science that touches the social behavior among the community directly. The urgency of ethics becomes a sensitive issue since it connotes good, bad, right, or wrong values. To explore the treasury of Ethics in the past time, in this case in The Before Christ (BC) century, is very interesting since the era is known as the Pre-Scientific era which refers to a condition of humans were still far from modern scientific traditions. However, Ethics has developed even becoming a value measurement for living both theoretically and practically at that time even in a different form. This research examined more deeply about Aristotle's thoughts who lived in the BC Century. Although as a figure of Western Philosophy, Aristotle became a very influential figure in the Islamic world, especially Islamic figures of the Peripatetic School, such as Al Kindi, Al Farabi, and Ibn Sina. This research was a Library Research that attempted to reveal the construction and paradigm of Ethical values of Aristotle through his work entitled The Nichomachean Ethics. The ethical concept was reflected in the concept of Ethics in Islam as represented by Islamic Ethics Figures. The result found that the most fundamental difference between Aristotle and Islamic Ethics are ethical formulations. Aristotle's ethical formulation is realistic-materialism. For Aristotle, Goodness, Virtue, and Happiness are not abstract values, but all of them are real as empirical conditions. While Islam put ethics on two dimensions at once, they are realistic-materialism and theoretical-spiritualism.
\end{abstract}

Keywords: Ethics, Aristotle, Islam, Realistic-materialism, Theoretical-spiritualism.

\begin{abstract}
Abstrak
Etika merupan disiplin Ilmu yang tidak pernah gersang untuk dibicarakan. Selain kultur teoritik yang kaya nilai, Etika juga merupakan sikap terapan yang bersentuhan secara langsung dalam tindaktanduk kehidupan sosial masyarakat. Urgensi Etika juga dirasa sangat sensitif karena berkonotasi langsung dengan nilai baik, buruk, benar, atau salah. Sangat menarik bila menggali khasanah Etika pada abad Sebelum Masehi (SM) karena secara historis, abad Sebelum Masehi (SM) dikenal dengan istilah Prasaintifik yang berarti manusia masih jauh dari tradisi keilmuan modern, namun demikian Etika baik secara teoritik maupun secara praktis sudah berkembang bahkan menjadi ukuran nilai kehidupan masyarakat pada waktu itu walaupun dengan format yang berbeda. Penelitian ini akan menelitik lebih dalam pemikiran Tokoh Abad Sebelum Masehi, Aristoteles. Walaupun sebagai Tokoh Filsafat Barat, Aristoteles juga merupakan tokoh yang sangat berpengaruh bagi dunia Islam terhususnya Tokoh Islam penganut Aliran Paripatetik seperti Al Kindi, Al Farabi, dan Ibnu Sina. Penelitian ini merupakan Library Research, Peneliti mencoba membedah konstruksi dan paradigma nilai Etika yang dibangun oleh Aristotele dalam karyanya yang berjudul The Nichomachean Ethics. Kemudian peneliti merefleksikan konsep tersebut dengan konsep Etika yang dinarasikan dan dibangun dalam Islam yang representasikan oleh Tokoh Etika Islam. Dalam penelitian ini, Penulis menemukan rumusan etika Aristoteles yang bersifat realistis-materialisme. Bagi Aristotelel, Kebaik, Kebajikan, dan Kebahagiaan bukalah sebuan nilai yang bersifat abstrak, namun kesemuanya itu merupakan sebuah keaadan yang bersifat real dan empirik. Ada perbedaan yang cukup mendasar dengan Etika Islam, Islam menempatkan keutamaan Etika pada dua dimensi sekaligus yakni realistis-meterialisme dan teoritis-spiritualisme.
\end{abstract}

Kata Kunci: Etika, Aristoteles, Islam, Realistis-meterialisme dan Teoritis-spiritualisme.

Accepted: 22-12-2019; reviewed: 22-01-2020; published: 04-06-2020

Citation: Ahmad Habibi, 'Diskursus Etika Artistoteles dalam Islam', Mawa'izh: Jurnal Dakwah dan Pengembangan Sosial Kemanusiaan, vol. 11, no. 1 (2020), pp. 97-122. 


\section{A. Pendahuluan}

$\mathrm{S}$ ecara historis, perbincangan Etika mulai berkembang pada abad ke 5 SM. Mulai dari seorang tokoh berkebangsaan Yunani bernama Parmenides memulai sebuah kajian metafisika dengan kalimat yang terkenal "being as being, being as such"yang diartikan "yang ada, sejauh yang ada". Kajian ini terus berkembang hingga zaman keemasan fisafat Yunani pada masa sofistik di Athena. Kaum sofis merupakan tokohtokoh yang memfokuskan diri mempelajari teori-teori yang difokuskan kepada manusia sebagai objeknya. ${ }^{1}$ Dari mereka kemudian pembahasan mengenai manusia menyentuk wilayah motif dari setiap tindakan manusia. Kajian Etika mendapatkan tempatnya yang cukup serius di tangan bapak filsafat Moral, Socrates, yang hidup pada masa sofistik.

Walaupun hidup pada masa Sofistik, Socrates merupkan tokoh yang menentang ajaran kaum sofis khususnya Pratogoras yang mengatakan bahwa "manusia adalah ukuran segala-galanya”. Mereka menganggap bahwa tidak ada sesuatu apapun yang baik dan bagus, semuanya adalah benar dalam hubungannya dengan manusia. Bagi Socrates bahwa "yang benar" dan "yang baik" sebagai nilai-nilai yang objektif dan harus dijunjung oleh semua orang sudah terkandung dalam batin setiap manusia, yakni sebuah tolok ukur kebaikan dan kebenaran dalam diri manusia. ${ }^{2}$ Pikiran-pikiran Socrates tersebut kemudian dicatat dan diajarkan kembali dengan berbagai pengembangan dan modifikasi oleh dua filsuf besar setelahnya, yaitu Plato dan Aristoteles. Walaupun keduanya dipengaruhi oleh pemikiran Socrates namun mereka memiliki paradigma serta epistemologi yang berbeda dalam merumuskan konsep etika. Plato berangkat dari alam ide ke alam real (idealisme) untuk menerjemahkan nilai moral universal yang diandaikan sudah ada dalam setiap batin manusia, sedangkan Aristoteles sebaliknya. Ia berangkat dari alam real ke alam idea (realistis).

Aristoteles bukan filsuf yang terlahir di Athena tetapi ia merupakan filsuf besar dan paling berpengaruh setelah Socrates dan Plato di Athena. Walaupun 20 tahun menjadi murid Plato, Aristoteles secara tegas menolak konsep Idea yang digagas oleh gurunya itu. Dia berpendapat bahwa tidak ada idea-idea yang bersifat abadi. Menurutnya idea-idea yang dimaksud oleh Plato adalah bentuk abstrak yang tertanam dalam realitas indrawi

\footnotetext{
${ }^{1}$ K. Betens, Ringkasan Sejarah Filsafat (Yogyakarta: Kanisius, 2011), p. 10.

2 Ibid., pp. 11-2.
} 
manusia itu sendiri. ${ }^{3}$ Oleh sebab itu, Aristoteles dijuluki dengan bapak filsuf realistik. Etika bagi Aristoteles, dengan demikian bukan sepenuhnya berada pada wilayah metafisik. Sebaliknya, ia meyakini bahwa keranga universalitas etika tidak bisa terlepas dari tindakan manusia di dunia fisik. Sekalipun ia meyakini bahwa tujuan moral dari tindakan manusia adalah sesuatu yang disepakati secara umum, ia meyakini bahwa tujuan moral tersebut terangkai dari aktivitas manusia dalam kehidupan sehari-hari. Karya Aristoteles, yang dalam terjemahan bahasa Inggris disebut The Nicomachean Ethics, mendapat tempat yang sangat berpengaruh terhadap kajian etika setelahnya, bahkan hingga mempengaruhi kajian etika dalam kebudayaan agama-agama. Menurut kesaksian tradisi, sebagaimana ditulis oleh K. Bertens, karya ini diberi nama begitu, karena telah disusun oleh anaknya yang bernama Nikomakhos sepeninggal ayahnya. ${ }^{4}$

Dalam kebudayaan Islam, pengaruh pemikiran Yunani terlihat sangat mencolok pada masa Dinasti Abbasiyah yang merupakan masa Keemasan dalam Islam. Di masa itu umat Islam memiliki gairah yang tinggi terhadap ilmu pengetahuan. Selain kebutuhan yang besar terhadap ilmu pengetahuan, penghargaan kerajaan juga sangat tinggi kepada para akademisi bahkan mereka memiliki status sosial yang tinggi pada masa itu. Hal ini ini tidak dipungkiri, bahkan pada masa kepemimpinan Al Makmun, karya ilmiah seorang akademisi bisa ditukar dengan emas dengan berat seberat hasil karya tersebut. Pada masa ini, penerjemahan besar-besaran dialukan oleh para akademisi. Karya-karya besar dari berbagai wilayah seperti Persia, Sanskrerta, Syiria, dan Yunani diterjemahkan ke dalam bahasa Arab dengan tujuan bisa dipahami dengan mudah oleh seluruh umat muslim yang ingin menggali ilmu pengetahuan. Gerakan penerjemahan ini berlangsung pada tahun 750 M samapai 850 M. ${ }^{5}$ Di masa ini pula pikiran-pikiran Aristoteles dipelajari dan mempengaruhi kebudayaan Islam.

Kajian etika dalam Islam secara teoretis memang tidak sepenuhnya berdasar dari etika Yunani, terutama pemikiran Aristoteles. Islam sendiri secara normatif diyakini memiliki spirit etika. Islam melalui Al Qur'an mengajarkan kepada manusia tentang etika yang lebih dalam yakni etika religious (etika spiritual). Etika religius terlahir dari

\footnotetext{
3 Franz Magnis-Suseno, 13 Tokoh Etika sejak Zaman Yunani sampai Abad ke-19 (Yogyakarta: Kanisius, 2015), p. 27.

${ }^{4}$ K. Bertens, dalam "Pengantar", Aristoteles, Nicomachean Ethics: Sebuah "Kitab Suci" Etika, terj. Embun Kenyowati (Jakarta: Teraju, 2004), p. v.

${ }^{5}$ Abdul Razak, Filsafat Etika Islam (Bandung: Pustaka Setia, 2011), p. 63-4.
} 
konsepsi-konsepsi yang berasal dari Maha Metafisik, Allah Swt. Etika Islam ngarahkan manusia secar universal untuk memahi hikum-hukum, pandangan-pandangan, falsafar, serta cara-cara hidup di dunia ini. Tidak hanya itu, sebagai penganut agama yang mengajarkan manusia untuk beriman kepada hari akhir (eskatalogi), umat Islam juga dikonsepsikan untuk melakukan riual ibadah sebagai bentuk etika eskataogi untuk menyelamtkan manusia dari kebinasaan.

Begitu juga dalam dimesi praktis. Etika Islam menuntun sekaligus mengajarkan manusia bagaimana bertindak-tanduk dalam kehidupan sehari-hari. Dalam aspek etika pribadi misalnya, Islam mengajarkan manusia untuk menghormati diri sendiri dengan selalu menjaga pola hidup sehat, disiplin, selalu berdo'a sebelum dan sesudah melakukan aktifitas apapun dan sekecil apapun. Dalam aspek sosial misalnya, Islam mengajarkan manusia supaya menghormati tetangga, mendermakah harta, bahkan menebarkan senyum dan menyapa dengan salam. Namun tidak dapat dipungkiri, persinggungan antara kebudayaan Islam dengan Yunani secara intelektual telah memberikan sumbangsih besar dalam penafsiran etika Islam, baik itu dalam wilayah pemikiran filsafat, syariat, bahkan tasawuf. Dalam konteks inilah penelitian ini dibangun. Melalui perspektif Islam, penelitian ini berusaha menyingkap berbagai kesamaan dan perbedaan dalam keterpengaruhan pemikian etika Aristoteles yang tertuang dalam karyanya The Nicomachean Ethics terhadap bangunan etika atau moral dalam Islam.

Dalam konteks penelitian ini pula, etika dan moral tidak memiliki posisi yang berbeda dalam kehidupan praktis. Etika berasal dari kata Latin yaitu "ethic" yang berarti kebiasaat atau habit. Dalam bahasa Yunani "ethicos" atau a body of moral principle or values. ${ }^{6}$ Etika ialah filsafat tentang tindakan manusia sebagai manusia (human action). Etika ialah filsafat yang berurusan dengan perbuatan manusia sejauh manusia. Apa yang dimaksud dengan "action" di sini ialah menunjuk pada terminologi Aristotelian, "praxis", yang berbeda dengan "theoria" atau spekulasi. "Praxis" ialah tindakan konkret yang langsung berkaitan dengan aktivitas kreatif, produktif, transformatif. Pendek kata, "praxis" (praksis) adalah tindakan yang bukan merupakan "theoria" (spekulatif). Praksis yang digumuli etika langsung berkaitan dengan tindakan manusia secara keseluruhan

${ }^{6}$ Muhammad Alfan. Filsafat Etika Islam (Bandung: Pustaka Setia, 2011), p. 17. 
dari sudut pandang normatif.7 Dalam bahasa yang sedikit berbeda, menurut M. J. Langeld bahwa etika adalah teori tentang perbuatan manusia ditimbang menurut baik dan buruknya. ${ }^{8}$ Dalam kajiannya, etika sering kali dikaitkan dengan moral atau filsafat moral.

Dalam Islam, istilah etika atau filsafat moral dikenal dengan istilah "Akhlaq". Akhlak didefinisakan sebagai aturan-aturan normatif yang dirumuskan oleh Al-Qur'an dan Sunnah. Dalalam makna yang lebih luas, Akhlak adalah sebuah "produk jadi" yang disuguhkan oleh ajaran Islam sebagai bingkai norma-norma kehidupan bagi umat Islam. Atau dalam narasi lain, Akhlak merupakan konsepsi moralitas bagi umat Islam yang bersifat normatif. ${ }^{9}$ Dalam wilayah filsafat Islam, menurut Al-Kindi (bapak Filsafat Islam), sebagaimana ditulis oleh George N. Atiyen, bahwa tujuan akhir filsafat adalah terletak pada moralitas (lahirlah filsafat moral), sedangkan tujuan etika adalah untuk mengetahui kebenaran kemudian berbuat sesuai dengan kebenaran tersebut (perbuatan untuk mencapai moralitas ideal). ${ }^{10}$ Sehingga secara umum, dalam konteks penelitian ini, etika dan moral memiliki posisi yang sama dalam wilayah tindakan manusia, meskipun secara literal barangkali berbeda. dalam konteks ini pula, "etika" dalam pandangan Aristoteles dengan "etika" dalam diskursus Islam dapat disejajarkan untuk dilihat titik temunya.

\section{B. Biografi Aristoteles}

Aristoteles (Aristotle) lahir di Stagira Macedonia (daerah Thrakia) Yunani pada tahun 384 SM. Ia memiliki kepala yang botak, tubuh kurus, cadel dan bermulut tajam. ${ }^{11}$ Ayahnya bernama Nicomachus, seorang dokter khusus bagi raja Macedonia Amyntas II. Pada umur 17 tahun Aristoteles belajar di Akademia Plato di Athena, dan pada tahun 345 SM Aristoteles hijrah ke Mytilence di Pulau Lesbos untuk melakukan riset zoologis. Kemudian pada tahun 342 sampai 340 SM dia menjadi tutor Aleksander Agung yang masih muda di Kerajaan Raja Philippus dari Makedonia. Mungkin sekali dalam masa mudanya ia hidup di istana Raja Makedonia di kota Pella dan dapat diandaikan pula

\footnotetext{
${ }^{7}$ Agustinus W. Dewantara, Filsafat Moral (Yogyakarta: Kanisius, 2017), p. 4.

${ }^{8}$ Muhammad Alfan. Filsafat Etika Islam., p. 26.

9 Amin Abdullah, Falsafah Kalam di Era Postmodernisme (Yogyakarta: Pustaka Pelajar, 2009), pp.146-7.

10 Muhammad Alfan. Filsafat Etika Islam., p. 17.

11 Paul Edwards (ed.), The Encyclopedia of Philosophy, vol. I-II (New York: Macmillan Publishing, 1967), p. 8-9. Lihat juga Robert Maynard Hutchins ed., Great Books of the Western World, vol. VII (USA: University of Chicago Press, 1989), pp. v-vi.
} 
bahwa ia mewarisi minatnya yang khusus untuk ilmu pengetahuan empiris dari ayahnya. $^{12}$

Ia juga mendirikan sekolah yang bernama Lycaeum (Lykaio) sekembalinya ke Athena pada tahun 335 SM yang menjadi cikal-bakal kemunculan satu bentuk filsafat yang khas dari Aristoteles yang disebut dengan paripatos atau paripatetik. Sekolah Peripatetik merupakan pusat penelitian ilmiah yang mendasarkan pada empirisme. Berbeda dengan Akademia, yang mengajarkan warisan Plato tentang ide-ide kepada murid-muridnya. ${ }^{13}$ Ketika semaraknya sentimen anti-Macedonia tepatnya setelah kematian Aleksander Agung, Aristoteles bersama keluarganya mengungsi ke Chalcis. Pengungsian ini terjadi salah satunya karena Aristoteles dituduh menyebarkan ateisme, ia memilih mengungsi karena tidak ingin tuduhan tersebut berujung pada nasib yang sama seperti yang dialami oleh Sokretes yang dipaksa meminum racun karena dituduh yang sama. Pada tahun 322 SM Aristoteles meninggal di Chalcis pada usia 62 tahun.

Adapun karya-karya Aristoteles sebagai berikut: ${ }^{14}$

1) Bidang Etika
I. Nichomachean Ethics
II. Magna Moralia (moral)
III. Eticha Eudaimania

2) Bidang Logika

I. Categoriae (kategori-kategori)

II. De Interpretation (perihal penafsiran)

III. Analytica Priora (analitika atau logika yang lebih dahulu)

IV. Analytica Posteriora (analitika yang kemudian)

V. Topica (topik)

3) Bidang Kosmologi
I. Physica (fisika)
II. De Caelo (perihal langit)

\footnotetext{
12 Rusfian Effendi, Filsafat Kebahagiaan (Yogyakarta: Penerbit Deepublish, 2017), p. 20.

13 Ibid., p. 20.

${ }^{14}$ Masykur Arif Rahman, Buku Pintar Sejarah Filsafat Barat (Yogyakarta: IRCISOD, 2013), pp. 166-
} 7. 
III. De Generatione et Corruptione (tentang timbulnya makhluk-makhluk jasmani)

IV. Meteoro Logika (tentang jagad raya)

4) Bidang Psikologi

I. De Anima (jiwa-jiwa)

II. Parva Naturalia (karangan-karangan kecil tentang pokok-pokok alamiah)

5) Bidang Biologi

I. De Partibus Animalium (bagian-bagian binatang)

II. De Motu Anamilium (perihal gerak bintang-binatang)

III. De Incessu Animalium (tentang hal berjalan binatang-binatang)

IV. De Generatione Animalium (kejadian binatang-binatang)

6) Bidang Metafisika

I. Metaphysica (filsafat pertama)

II. Theologia (ketuhanan)

7) Bidang Politik dan Ekonomi

I. Politica (politik)

II. Economica (ekonomi)

8) Bidang Retorika dan Poetika

I. Rhetorica (retorika)

II. Poetica (puisi)

\section{Perspektif Aristoteles Tentang Manusia dan Etika}

Berbeda dengan Plato, konsep manusia Aristotes sangat bertolak belakang dengan konsep manusia menurut gurunya, Plato. Plato mengemukakan bahwa manusia terdiri dari idea-idea yang bersifat abstrak sedangkan Aristoteles menggap bahwa manusia manusia adalah makhluk konkret. Menurutnya, klasifikasi manusia bersifat spesifik yakni manusia ini, atau manusia itu, sifatnya konkret dan bisa diselidiki. Perbedaan pandangan yang fundamental ini ditegaskan dengan perkatan Aristoteles "Amicus Plato, magis amica veritas" (Plato memang sahabatku, tetapi kebenaran lebih dekat bagiku). ${ }^{15}$ Menurut

15 K. Bertens, Ringkasan Sejarah Filsafat., p. 15. 
Aristoteles, Manusia merupakan makluk jasmani yang memiliki meteri dan bentuk. Kedua tidak bisa bisa dipisahkan dan sudah terbentuk secara konstruktif. Manusia merupakan substansi yang hidup dan menyatu dalam sebuah kombinasi jiwa dan fisik. Bagi Aristoteles, bentuk manusia adalah jiwa dan materinya. Dalam klasifikasi semacam ini kemudian Aristoteles memposisikan Etika sebagai cabang ilmu alam tentang manusia yang menggambarkan apresiasi samar terhadap kompleksitas motivasi manusia. ${ }^{16}$

Menurut Aristoteles, setiap benda yang konkret memiliki bentuk dan materi. Dia memberikan contoh tentang sebuah patung. Setiap patung terdiri dari bahan tertentu dan bentuk tertentu. Lebih spesifik lagi misalnya patung kuda. Materi patung kuda adalah tanah dan batu sedangan bentuk dari patung tersebut adalah kamuflase wujud sebuah binatang yakni kuda. Dengan demikian, Aristoteles ingin mengatakan bahwa patung kuda terdiri dari materi tanah dan batu dan terdiri dari bentuk yakni wujud dari kuda. ${ }^{17}$ Namun demikian, Arisoteles menyebutkan bahwa setiap materi tidak terbatas dalam ruang yang fisik saja, namun bisa menyentuh hal yang bersifat metafisik. Artinya tidak semua materi bisa ditunjuk dengan jari atau terlihat oleh mata. Secara prinsipel bahwa materi adalah prinsip yang sama sekali tidak ditentukan dan bersifat "terbuka". Materi adalah suatu ruang yang bekemungkinan untuk menerima sebuah bentuk. Dengan kata lain bahwa materi (materi pertama, hyle prote) selalu memiliki bentuk ia adalah prinsip yang akan menentukan sebuah bentuk. ${ }^{18}$

Dalam disiplin etika atau moral, seringkali yang menjadi pusat persoalan adalah pertanyaan tentang makna "yang baik" dalam tindakan manusia. Tidak mengherankan bahwa "yang baik" kemudian menjadi istilah khas dalam persoalan etika atau moral. Setiap tindakan manusia, motif, dan tujuan hidupnya digeluti untuk menentukan makna kebaikan di dalamnya yang dapat dijadikan pijakan hukum dan batasan moral. "Baik" sendiri dalam Kamus Besar Bahasa Indonesia didefinisikan sebagai "patut, teratur, tidak ada celanya". Sedangkan kebaikan adalah sifat manusia yang dianggap baik menurut

\footnotetext{
16 Pendapat ini berbeda dengan pendapat Plato bahwa etika merupakan puncak dari semua pengetahuan yang merupakan motivasi pengetahuan terbesar manusia. Simon Blackburn, Kamus Filsafat. edisi ke-2 terj. Yudi Santoso (Yogyakarta: Pustaka Pelajar, 2013), p. 58.

17 K. Bertens, Ringkasan Sejarah Filsafat (Yogyakarta, Kanisius, 2012), p.15.

18 Ibid.,
} 
sistem norma atau pandangan umum yang berlaku (convention). ${ }^{19}$ Akan tetapi dalam buku "The Nicomachean Ethics" Aristoteles mengatakan bahwa kebaikan yang ia maksud berbeda sebagaimana yang telah dirumuskan oleh Socrates dan Plato karena dipandang sangat konseptual dan berdimensi dalam ranah ide. Dalam buku transliterasi ke bahasa Inggris kebaikan yang dimaksudkan oleh Aristoteles diterjemahkan dengan kata "good". Secara definitif, Aristoteles tidak mengartikan apa itu kebaikan namun menurutnya terdapat berapa prinsip dasar mengenai kebaikan (1) kebaikan harus berangkat dari fakta (2) kebaikan harus dipikirkan dan diusahakan (3) kebaikan merupakan tujuan dari segala tindakan. ${ }^{20}$ Sebagaimana Aristoteles mengawali karyanya, The Nicomachean Ethics, dengan menegaskan sifat dasar tindakan manusia, yaitu mengarah pada tujuan yang baik. Sehingga "yang baik" menurutnya adalah sesuatu di mana semua hal mengarah padanya. $^{21}$

Berbeda dengan pendapat Plato bahwa baik digunakan dalam substansi, kualitas dan relasi yang memiliki bentuk (form) sendiri dan berdiri sendiri yang mendahului hubungan yang dapat dimasukkannya. Menurut Aristoteles yang baik bukanlah elemen umum yang ada dalam hal tersebut sebagai asal dari suatu bentuk (form). Yang baik merupakan suatu yang beda dalam setiap tindakan dan berbeda dalam setiap cabang seni (For it appears to be one thing in one action or art, another in another). ${ }^{22}$ Oleh sebab itu baik dibagi menjadi tiga kelompok yang pertama baik dalam lingkup eksternal (external), kedua baik dalam tubuh (body), ketiga baik dalam jiwa (soul). Dari ketiga klaster tersebut, baik dalam jiwa merupakan kebaikan yang tertinggi.23 Maka yang terpenting dalam setiap tindakan adalah melakukan kebaikan tersebut bukan untuk mengetahui apakah kebaikan itu. ${ }^{24}$ Aristoteles menegaskan, yang baik bagi manusia adalah kegiatan jiwa dalam keselarasan dengan keutamaan atau kebajikan. Jika ada banyak kebajikan, keselarasannya adalah dengan yang paling baik dan yang paling sempurna. ${ }^{25}$

19 Tim Penyusun Kamus Pusat Pembinaan dan Pengembangan Bahasa, Kamus Besar Bahasa Indonesia, cet. ke-2, (Jakarta: Balai Pustaka, 1989), pp. 67-8.

${ }^{20}$ Robert C. Bartlett dan Susan D. Collins, Aristotle's Nicomachean Ethics (Chicago: The University of Chichago Press. 2011), p. 11.

${ }^{21}$ Aristoteles, Nicomachean Ethics., p. 1.

22 Robert C. Bartlett dan Susan D. Collins, Aristotle's Nicomachean Ethics., pp. 8-10.

${ }^{23}$ Ibid., p. 15.

24 Ibid., pp. 27-8.

25 Aristoteles, Nicomachean Ethics., p. 14. 
Menurut Aristoteles yang baik bukanlah elemen umum yang ada dalam hal tersebut sebagai asal dari suatu bentuk (form). ${ }^{26}$ Yang baik merupakan suatu yang beda dalam setiap tindakan dan berbeda dalam setiap cabang seni (For it appears to be one thing in one action or art, another in another). ${ }^{27}$ Oleh sebab itu baik dibagi menjadi tiga kelompok yang pertama baik dalam lingkup eksternal (external), kedua baik dalam tubuh (body), ketiga baik dalam jiwa (soul). Dari ketiga klaster tersebut, baik dalam jiwa merupakan kebaikan yang tertinggi. ${ }^{28}$ Aristoteles mengutip kata Hesiod: “Orang yang baik adalah yang mengerti segala-sesuatu tentang dirinya sendiri”... (This one is altogether best who himself understands all things). ${ }^{29}$

Aristoteles mengklarifikasikan bahwa kebaikan akan disesuaikan dengan gender, posisi, profesi dan tujuan hidup seorang. Bagi seorang dokter, kebaikan adalah kesehatan yang baik. Bagi seorang pedagang, kebaikan adalah laba. Bagi seorang tentara, kebaikan adalah kemenangan. Lebih lanjut Aristoteles mengatakan bahwa kebaikan merupakan suatu tujuan. Dengan demikian maka semakin banyak tujuan maka semakin banyak kebaikan yang akan dicapai. ${ }^{30}$ Dari narasi kebaikan di atas maka dapat diasumsikan nampaknya Aristoteles mendefinisikan bahwa kebaikan bersifat "relatif". Dugaan tersebut berangkat dari argumen dia bahwa kebaikan dalam obat-obatan adalah kesehatan, kemenakan dalam strategi, dan rumah dalam sebuah bangunan. ${ }^{31}$

Kebaikan manusia adalah kegiatan jiwa dalam keselarasan dengan kebajikan dan kebajikan. Berbincang maslah kebaikan, bahwa yang terpenting adalah melakukan kebaikan tersebut bukan untuk mengetahui apakah kebaikan itu. Dengan tindakan maka tindakan yang kita lakukan harus memiliki alasan yang tepat dan bisa disetujui atau difteri oleh khalayak. ${ }^{32}$

${ }^{26}$ Robert C. Bartlett dan Susan D. Collins, Aristotle's Nicomachean Ethics, (Chicago: The University of Chichago Press. 2011), p. 11.

${ }_{27}$ Ibid., p. 10.

${ }^{28}$ Ibid., p. 15.

29 Ibid., p. 6.

30 Ibid., p. 11

31 In medicine, this is health; in generalship, victory; in house building, a house; and in another, it would be somethingelse Robert C. Bartlett dan Susan D. Collins, Aristotle's Nicomachean Ethics, (Chicago: The University of Chichago Press. 2011), p. 11.

32 Ibid., pp. 27-8. 


\section{Etika Kebajikan dan Kebahagiaan}

The Nicomachean Ethics memang dapat dibilang sebagai karya filsafat moral yang paling fenomenal. Karya ini banyak mempengaruhi bangunan filsafat moral hingga saat ini. bahkan pikiran-pikiran Aristoteles yang tertuang dalam karya tersebut memiliki banyak nilai kontekstual di berbagai zaman. Akan tetapi karya tersebut jelas bukan karya yang mudah dibaca dan dipahami. Banyak statemen inti yang diulang, banyak contohcontoh tindakan yang dijelaskan panjang lebar dengan logika demonstrasinya yang khas. Pembaca mungkin dikecewakan dengan hasil yang sederhana dari penjelaskan yang begitu rumit. Demikian juga untuk memahami bagaimana etika menurut Aristoteles yang tertuang dalam karya tersebut, barangkali pula akan lebih mudah jika dimulai dari bagaimana Aristoteles menggambarkan tindakan manusia.

Aristoteles membagi kehendak manusia menjadi dua, kehendak bebas (voluntary) dan yang tidak bebas (involuntary). Thomas Aquinas, mengikuti Aristoteles, kemudian membagi tindakan bebas ini menjadi dua: directly voluntary yang berarti tindakan bebas di mana tujuan dari tindakan tersebut dapat dirasakan secara langsung dari hasil tindakan tersebut; dan indirectly voluntary yang berarti konsekuensi-konsekuensi dari tindakan bebas yang sebenarnya tidak dikehendaki. Dengan demikian, keutamaan tidak pernah merupakan indirectly voluntary. Keutamaan selalu harus merupakan tindakan yang sepenuhnya berada dalam kuasa sang pelaku sebagai subjek tindakan. Keutamaan tidak pernah merupakan tindakan yang tak disengaja, atau apalagi tidak dalam kehendaknya. Keutamaan mengandaikan manusia sebagai tuan atas tindakannya. ${ }^{33}$

Tujuan "yang baik" dalam setiap tindakan manusia juga mesti dihasilkan dari tindakan yang bebas dan tanpa paksaan. Tindakan yang didasari oleh kehendak hati untuk mencapai tujuan tentunya bukan tujuan sementara. Aristoteles menyadari bahwa dalam kehidupan manusia, ada banyak tujuan dalam banyak tindakan. Makan demi tujuan kenyang, pendidikan demi tujuan ijazah dan pekerjaan, bahkan ibadah demi tujuan memenuhi kewajiban, bagi Aristoteles hanyalah tujuan sementara. Tujuan yang semacam itu dapat diidentifikasi dari kehadiran tujuan lainnya. Menurutnya, tujuan "yang baik" bagi setiap tindakan manusia haruslah merupakan tujuan puncak dan absolut, yang seakan-akan dengan tercapainya tujuan tersebut manusia tidak lagi membutuhkan

\footnotetext{
${ }^{33}$ Agustinus W. Dewantara, Filsafat Moral., p. 17.
} 
sesuatu yang lain. Menurut Aristoteles, kebahagiaan adalah tujuan moral absolut dalam tindakan manusia. Kebahagiaan sebagai tujuan pada dirinya sendiri dan tidak pernah demi sesuatu yang lain. ${ }^{34}$ Pertimbangan yang paling rasional menurut Aristoteles dalam mendasari kehidupan bermoral adalah keterarahan pada kebahagiaan. ${ }^{35}$ Sehingga menurut Magniz Suseno, Aristoteles adalah filosof pertama yang merumuskan dengan jelas bahwa kebahagiaan adalah apa yang dicari semua orang. Karena itu etikanya disebut "eudemonisme", dari kata Yunani eudaemonia yang berarti "bahagia". 36

Kebahagiaan bagi Aristoteles berbeda dengan kebahagiaan dalam makna modern yang lebih bersifat individu dan subjektif. Dalam Kamus Besar Bahasa Indonesia misalnya, dijelaskan bahwa kebahagiaan adalah perasaan bahagia dengan kesenangan dan ketentaraan hidup (dunia-akhirat). ${ }^{37}$ Sama halnya dengan pespektif Hedonisme, bahwa kebahagiaan erat kaitannya dengan kesenangan individu. Apa yang menurut pribadi membawa kesenangan adalah tujuan dari tindakan, dan itu dikatakan baik. Menurut Aristoteles, hedonisme menerapkan cara hidup hewani kepada manusia, sehingga tidak membedakan manusia dengan binatang. ${ }^{38}$ Sehingga, ada hal fundamental yang membedakan pemikiran kaun Hedonis dan Eudemonis yang berketetapan bahwa kebahagiaan identik dengan materi.

Menurut pandangan Hedonis, materi merupakan unsur kebendaan yang dapat membuat manusia menjadi bahagia. Bagi Aristoteles, kebahagiaan bukan terletak pada materi, termasuk bukan pada jabatan atau kedudukan. Kebahagiaan sejati bukan terletak pada perolehan materi karena orang yang bahagian adalah orang yang tidak membutuhkan sesuatu. Apabila sesorang masih membutuhkan sesuatu maka bisa dikatakan orang tersebut belum bahagia. Berbeda pula dengan ciri khas ajarannya Plato tentang ideanya yang bercorak abstraksi, ajaran Arostoteles berangkat dari realitas empiris manusia. Maka, jalan pada kebahagiaan menurut Aristoteles adalah pemaksimalan potensi yang terdapat di dalam diri seseorang dan diarahkan ke luar dirinya dengan melakukan keutamaan-keutamaan. Berbeda dengan Plato yang

\footnotetext{
${ }^{34}$ Aristoteles, Nicomachean Ethics., p. 12.

35 Franz Magnis-Suseno, Menjadi Manusia Belajar Dari Aristoteles (Yogyakarta, Kanisius: 2009), p.

36 Ibid., p. 4.

${ }^{37}$ Kamus Besar Bahasa Indonesia., p. 65.

38 Franz Magnis-Suseno, Menjadi Manusia., pp. 13-4.
} 10. 
berpendapat bahwa kebahagiaan tercapai melalui kontemplasi atau penyatuan dengan Ide Yang Baik. ${ }^{39}$

Kita harus membedakan secara tegas antara kebahagiaan dan alat atau instrument yang mengantarkan pada kebahagiaan. Kebahagiaan sejati merupakan kebaikan yang tertingi "highest good" atau dalam karya lain Aristoteles menyebutnya sebagai summum bonum. ${ }^{40}$ Sehingga bagi Aristoteles, kebahagiaan yang dalam bahasa Yunani disebut eudaimonia adalah kebahagiaan yang menggambarkan keadaan objektif. Eudaimonia berarti mempunyai jiwa (daimon) dalam keadaan baik. Karena itu, menurut Bertens, daripada menerjemahkan eudaimonia dalam bahasa inggris sebagai happiness, lebih tepat digunakan kata well-being. ${ }^{41}$ Menurut Aristoteles, kebahagiaan tidak dapat dicapai dengan mengejar perasaan nikmat dan menghindari perasaan sakit, akan tetapi berfokus pada tindakan yang bermakna. 42

Apa yang membuat manusia bahagia bisa jadi berbeda-beda. Aristoteles menyadari hal tersebut, sehingga apa yang dikatakan Aristoteles sebagai kebahagiaan yang objektif bukan berarti menyamakan makna dan bentuk-bentuk kebahagiaan. Menurutnya, kebahagiaan dapat dicapai melalui pencapaian kebajikan atau keutamaan. Ia menempatkan keutamaan ini sebagai sifat dari setiap tindakan manusia. Menurutnya, keutamaan adalah sikap-sikap batin yang dimiliki manusia (hexis prohairetike). ${ }^{43}$ Menurutnya bahwa kebajikan merupakan sifat manusia yang akan menjadikannya baik dan menyebabkan dia menjalankan fungsinya secara baik..44 Bahwa kebahagiaan berkaitan langsung dengan virtue (keutamaan), yaitu aktivitas manusia yang melukiskan kesesuaiannya dengan akal budinya. Bahwa segala aktivitas hidup manusia terarah kepada kebaikan, dan apa yang merupakan kebaikan tertinggi adalah kebahagiaan.

Terdapat dua kebajikan atau keutamaan menurutnya: kebajikan intelektual atau keutamaan intelektual dan kebajikan moral atau keutamaan moral. ${ }^{45}$ Melalui pembagian ini, ia menempatkan tujuan moral pada pilihan keutamaan moral. Keutamaan moral

\footnotetext{
${ }^{39}$ Rusfian Effendi, Filsafat Kebahagiaan., p. 21.

${ }^{40}$ Robert C. Bartlett dan Susan D. Collins, Aristotle's Nicomachean Ethics., p. 369.

${ }^{41}$ K. Bertens, dalam "Pengantar", Aristoteles, Nicomachean Ethics., p. viii.

${ }^{42}$ Franz Magnis-Suseno, Menjadi Manusia., p. 19.

43 Rusfian Effendi, Filsafat Kebahagiaan., p. 25.

${ }^{44}$ Robert C. Bartlett dan Susan D. Collins, Aristotle's Nicomachean Ethics., p. 33.

45 Aristoteles, Nicomachean Ethics., pp. 28-9.
} 
berkaitan dengan kesenangan dan kesusahan. Kesenanganlah yang membuat kita melakukan perbuatan rendah dan kesusahann atau penderitaanlah yang menghalangi kita dari melakukan tindakan mulia. Atas dasar itu, seperti telah dikatakan oleh Plato, Aristoteles menegaskan bahwa orang harus dididik sejak kecil untuk merasakan kesenangan dan kesusahan pada tempatnya. ${ }^{46}$ Dalam tradisi Yunani, terdapat dua kata yang mengandung makna kebijaksanaan: Phronesis dan shopia. Sophia adalah kebijaksanaan dalam arti kemampuan manusia untuk memandang yang ilahi, yang abadi. Sedangkan pronesis adalah kebijaksanaan dalam kehidupan sehari-hari. ${ }^{47}$ Aristoteles mendefinisikan phronesis sebagai "kebijaksanaan bertindak berdasarkan pertimbangan yang tepat dalam bidang masalah baik dan buruk bagi manusia". 48

Dalam konteks inilah Aristoteles menegaskan bahwa pertimbangan moral yang rasional adalah pertimbangan yang mengantarkan pada keutamaan moral yang dapat membuahkan kebahagiaan. Kedua bentuk keutamaan tersebut, menurutnya sama-sama dapat mengantarkan kepada kebahagiaan. Sehingga ia juga membagi kebahagiaan menjadi dua, yakni kebahagiaan teoritis dan kebahagiaan praktis. Kebahagiaan teoritis merupakan kebahagiaan yang bersifat abstrak dan tidak dapat dimaterikan. Kebahagiaan teoritis terletak pada akal budi manusia. Akal budi bisa mendatangkan kebahagiaan, dengan menggunakan akal budi untuk merenung (tafakkur) secara mendalam maka manusia dapat merasakan suatu kebahagiaan. Bagi Aritoteles, merenung merupakan sesuatu yang luhur dan membahagiakan. Sedangkan kebahagiaan praktis merupakan tindakan yang benar dan dilakukan dengan suka rela, tanpa paksaan, atau dengan senang hati. Implementasinya, tindakan yang mendatangkan kebahagiaan diwujudkan dalam berbagai komuntas kelurga, masyarakat, atau negara. Adapun tindakan yang tepat adalah tindakan yang mendatangkan manfaat bagi sesama. ${ }^{49}$

Dalam konteks demikian, dapat dipahami bahwa kutamaan moral terletak pada pencapaian kebahagiaan praktis, dimana kebahagiaan dapat dirasakan secara sosial. Berbeda dengan keutamaan teoretis yang hanya dapat mengantarkan kepada kebahagiaan intelektual, ia hanya menjadi kesempurnaan pribadi manusia dalam berpikir

\footnotetext{
46 Ibid., p. 33.

47 Franz Magnis-Suseno, Menjadi Manusia., p. 36-7.

48 Ibid., p. 38.

${ }^{49}$ Robert C. Bartlett dan Susan D. Collins, Aristotle's Nicomachean Ethics., p. 16
} 
dan melakukan pertimbangan. Sehingga dapat disimpulkan, bahwa seakan-akan Aristoteles mengharapkan keutamaan yang sempurna bagi tindakan manusia, di mana ada keseimbangan antara keutamaan teoretis dan keutamaan praktis. Keutamaan teoretis membuat manusia mampu memilih tujuan yang paling baik di antara berbagai tujuan, kemudian melalui keutamaan praktis pertimbangan tersebut diaplikasikan dalam realitas sehari-hari. Tidak mengherankan jika Aristoteles memberikan nilai yang tinggi pada bidang filsafat, sebagai bidang yang mengajarkan manusia mencapai keutamaan teoretis.

Berdasarkan cara kerja rasio, Aristoteles membagi filsafat ke dalam dua jenis, filsafat teoretis dan praksis. Teoretis berasal dari kata theoria yang berasal dari bahasa Yunani, memiliki arti memandang. Filsafat teoretis adalah cara akal dalam melihat, merenungkan, memahami dan mencari penjelasan ke dalam tentang segala yang ada serta perubahan-perubahan yang terjadi. Sedangkan filsafat praksis merupakan penyelidikan terhadap perilaku atau tindakan manusia, bagaimana manusia harus bertindak, baik secara individu maupun tindakan yang diarahkan ke ranah sosial. ${ }^{50}$ Dalam makna yang demikian itu, Aristoteles menegaskan bahwa filsafat adalah tempat di mana manusia mengangkat rohnya di atas alam yang berubah, melampaui wilayah keniscayaan fisik, mengatasi keterbatasannya sebagai makhluk di waktu dan tempat tertentu. ${ }^{51}$ Seakanakan dapat dipahami bahwa hanya dengan filsafatlah seseorang dapat mencapai kebahagiaan puncak, karena dengan filsafat seseorang dapat memilh tujuan yang bijaksana dan bertindak secara bijaksana. Sebagaimana dijelaskan oleh Rusfian Effendi, bahwa dengan ilmu pengetahuan yang rasional akan megantarkan seseorang untuk bisa sampai kepada sumber kebahagiaan. Akal yang terus diisi oleh ilmu pengetahuan membuat seorang filsuf bisa bergerak kepada kebenaran, yang muaranya adalah kebahagiaan. ${ }^{52}$

Selain itu, untuk dapat mencapai keutamaan yang paling unggul, manusia harus dapat memilih di antara berbagai pilihan. Dalam hal ini, Aristoteles memposisikan kebajikan atau keutamaan tersebut pada posisi tengah-tengah di antara dua sifat yang saling berseberangan. Ia mengatakan, kebajikan atau keutamaan bertujuan pada jalan tengah. Artinya, ia adalah sifat yang melibatkan pilihan dan terdapat dalam pencarian

\footnotetext{
${ }^{50}$ Rusfian Effendi, Filsafat Kebahagiaan., p. 21.

51 Franz Magnis-Suseno, Menjadi Manusia., p. 27.

52 Rusfian Effendi, Filsafat Kebahagiaan., p. 33.
} 
jalan tengah yang relatif terhadap kita. ${ }^{53}$ Kebajikan moral akan dipengaruhi oleh kekurangan (defect) dan kelebihan (excess). Hal demikian bisa kita analogikan seperti kegiatan olahraga yang kurang dan berlebihan akan merusak badan atau kurang makan, terlalu banyak makan juga akan merusak tubuh. Atau dalam contoh lain bahwa orang yang menghindar dan selalu takut atas segala tantangan akan menjadi pengecut. Dan orang yang selalu menantang bahaya akan menjadi gegabah. ${ }^{54}$ Dalam anaoli yang lain, jika kelebihan adalah keborosan dan kekikiran adalah kekurangan maka jalan tengahnya adalah kedermawanan. Jika kelebihan adalah kehormatan yang lebih dan ketidakhormatan adalah kekurangan maka jalan tengahnya adalah kebesaran jiwa. Jika kelebihan adalah kemarahan dan mati rasa (apathy) adalah kekurangan maka jalan tengahnya adalah kelembutan. Jika kelebihan adalah kesombongan dan adalah kekurangan rendah diri maka jalan tengahnya adalah rendah hati. ${ }^{55}$

Banyak sekali contoh-contoh sifat dalam tindakan manusia yang disuguhkan oleh Aristoteles, semuanya ia analogikan berada dalam posisi yang berlawanan dan menjelaskan posisi tengah di antara keduanya sebagai posisi keutamaan moral. Sekalipun begitu, ia mendasarkan kemampunan memilih kepada pribadi masing-masing. Dalam hal ini ia menempatkan pendidikan moral sebagai suatu pelajaran yang bernilai yang harus diasah oleh diri sendiri. Untuk mencapai jalan tengah maka seseorang harus pandai menjadi seorang juri agar tidak terlalu menikmati kelebihan atau jatuh ke dalam kekurangan, yang diharapkan adalah berada ditengah-tengahnya atau seimbang (balance). ${ }^{56}$ Aristoteles mengatakan bahwa kita harus secara khusus menjaga diri terhadap kesenangan dan apa yang menyenangkan, karena saat kita sampai pada kesenangan kita tidak dapat bertindak sebagai juri atau penilai yang tidak bias. ${ }^{57}$

Persoalan kemudian adalah munculnya kembali anggapan bahwa kebahagiaan sebagai buah dari keutamaan moral menjadi pencapaian individu dan bersifat subjektif. Anggapan semacam ini menjadi wajar dikarenakan Aristoteles mendasarkan pilihanpilihan moral pada individu masing-masing. Dalam banyak contoh keutamaan yang dijelaskan dalam The Nicomachean Ethics, sebenarnya anggapan semacam itu tidak dapat

\footnotetext{
${ }^{53}$ Aristoteles, Nicomachean Ethics., pp. 39-40.

${ }^{54}$ Robert C. Bartlett dan Susan D. Collins, Aristotle's Nicomachean Ethics., pp. 28-9.

55 Ibid., pp. 36-7.

56 Ibid., p. 41.

${ }^{57}$ Aristoteles, Nicomachean Ethics., p. 47.
} 
dibenarkan. Penolakan Aristoteles atas konstruksi dunia ide universal Plato tidak lantas menghapus dasar objektif bagi keutamaan moral Aristoteles. Ia menempatkan politik dan hukum sebagai landasan objektif di mana keutamaan moral dapat ditegakkan dan dirasakan secara sosial. Aristoteles mengatakan bahwa politik menempati posisi fundamental di mana "yang baik" harus ditentukan secara sosial, sehingga tujuan politik adalah yang baik bagi manusia. ${ }^{58}$ Dalam politik, konstruksi keutamaan moral diatur, kebahagiaan diupayakan bersama melalui kerangka hukum positif yang disepakati bersama, dan dijalankan secara sosial.

Melalui politik pula keutamaan dapat diletakkan dalam klasifikasi konsep-konsep tindakan sosial di mana Aristoteles memposisikan keadilan sebagai keutamaan yang paling unggul yang dapat dirasakan bersama. Aristoteles mengatakan bahwa keadilan dianggap sebagai yang tertinggi di antara keutamaan lainnya, lebih mengagumkan dari bintang pagi dan bintang malam hari dan seperti yang diungkapkan pepatah "dalam keadilan semua keutamaan diringkas". Keadilan menjadi lengkap karena siapa yang memilikinya dapat menggunakan kebajikannya bukan oleh dirinya sendiri, tetapi juga dalam hubungannya dengan orang-orang di sekitarnya, karena banyak orang yang dapat menggunakan kebajikannya untuk urusannya sendiri tetapi tidak mampu menggunakannya dalam hubungannya dengan orang lain. 59

Melalui politik pula hukum positif dapat ditetapkan untuk memilih posisi tengah yang objektif. Keadilan, bagi Aristoteles, juga merupakan posisi tengah yang didasari oleh hukum tersebut. Ia mengartikan ketidakadilan dalam arti "tidak mengikuti hukum" dan dalam arti "tidak jujur/tidak adil", sementara keadilan yang berarti "mengikuti hukum/atau aturan" dan dalam arti "jujur/adil". ${ }^{60}$ Karena yang sama rata adalah jalan tengah, maka yang adil juga merupakan jalan tengah. ${ }^{61}$ Yang adil hanya ada di antara orang-orang yang hubungannya diatur oleh hukum, dan hukum ada di mana ketidakadilan mungkin terjadi. ${ }^{62}$ Perhatiannya yang besar terhadap politik dan hukum mengindikasikan bahwa etika menurtnya bukanlah persoalan yang subjektif semata sebagaimana kaum Hedonisme. Ia seakan membayangkan realitas yang bahagia adalah
58 Ibid., p. 2.
59 Ibid., p. 114.
60 Ibid., p. 116.
61 Ibid., p. 118.
62 Ibid., p. 128. 
konstruksi realitas politik dan hukum yang utama, di mana tidak ada satu pihak pun menyangkal batasan-batasannya. Dengan pemahaman seperti ini pula dapat dikatakan bahwa Aristoteles menyetujui anggapan Plato dalam konsteks bahwa seorang pemimpin haruslah seorang filosof. Keunggulan yang diberikan Aristoteles kepada filsafat sebagai cara untuk memperoleh keutamaan intelektual, seakan-akan sejalan dengan pikiran Plato bahwa melalui pemimpin yang bijaksana negara utama dapat terwujud. Dalam arti melalui pemimpin yang bijaksana kebahagiaan dapat dirasakan secara umum.

Sekalipun begitu, Plato hanya mendasarkan negara utamanya pada seorang pemimpin, sementara Aristoteles, sekalipun menempatkan filsafat dan politik sebagai jalan berseminya kebahagiaan, juga mengharapkan keutamaan moral diupayakan bersama-sama. Di sinilah ia, dalam dua bagian terakhir karyanya, membahas mengenai pentingnya persahabatan. Ia mengatakan, manusia mencapai puncak keutamaan dalam persahabatan sejati.63 Persahabatan dalam arti yang sebenarnya adalah persahabatan demi sahabat, persahabatan karena dua sahabat saling mencintai, karena keutamaan di antara para sahabat adalah cinta. ${ }^{64}$ Bahkan ia membalikkan anggapan bahwa seakan-akan hanya melalui politik kebahagiaan dapat diandaikan. Persahabatan, sekalipun dalam The Nicomachean Ethics, menjadi pembahasan tersendiri dengan politik dan hukum, dapat diandaikan sebagai bagian dari hukum moral yang tidak tertulis (hukum non-positif) yang ada dalam kehidupan sosial. Aristoteles menegaskan, persahabatan lebih penting daripada keadilan. Sebab, kalau orang-orang bersahabat, dengan sendirinya keadilan timbul di antara mereka. 65

\section{E. Tinjauan Etika Islam Terhadap Etika Aristoteles}

Berbeda dengan tradisi Yunani, di mana persoalan etika adalah murni persoalan motif tindakan manusia menuju tujuannya yang paling mulia, etika dalam Islam erat kaitannya dengan persoalan hubungan antara Tuhan dengan manusia di dunia. Sekalipun di dalamnya terdapat poin-poin yang menetapkan bagaimana seharusnya hubungan tindakan antar manusia, hubungan tersebut sejatinya diturunkan dari ketetapan Tuhan yang telah mengatur segala urusan manusia di dunia. Sekalipun begitu, beberapa peneliti

\footnotetext{
63 Franz Magnis-Suseno, Menjadi Manusia., p. 52.

64 Ibid., p. 53.

${ }^{65}$ Aristoteles, Nicomachean Ethics., p. 210.
} 
juga menetapkan nilai teologis pada etika Aristoteles, namun bukan teologi dalam arti religiusitas. Seperti menurut Bertens, bahwa ada dua inti pemikian Aristoteles dalam karya ini: pertama, sifatnya yang teologis, yaitu keterarahan pada tujuan (telos), dan kedua adalah etika keutamaan. ${ }^{66}$ Begitu pula Dewantara, mengatakan bahwa etika kebaikan Aristotelian bersifat teologis, yaitu menuju kepada kebahagiaan. ${ }^{67}$ Dalam hal ini, nilai teologis dalam etika Aristoteles hanya dipandang dari tujuannya kepada pencapaian kebahagiaan, yang menurut Aristoteles sejatinya didasari dari gerak jiwa manusia.

Etika dalam Islam, sebaliknya, memiliki struktur konseptual dan penafsiran yang sangat luas. Etika yang paling penting, yang paling utama, mencakup seluruh etika dalam Islam, baik berupa perkataan maupun perbuatan, dan menjelaskan semua etika, adalah etika kepada Allah dan Rasulullah SAW. Itulah makna agama yang sesungguhnya. ${ }^{68} \mathrm{Ibnu}$ Qayyim mengatakan, sebagaimana ditulis oleh Badruzaman, bahwa agama adakah akhlak. ${ }^{69} \mathrm{Al}$-Qur'an adalah ajaran yang terutama berkepentingan untuk membina sikap moral yang benar bagi tindakan manusia. Tindakan yang benar, apakah itu tindakan politik, keagamaan ataupun sosial, dipandang Al-Quran sebagai ibadah atau "pengabdian kepada Tuhan". karena itu, Al-Quran menekankan tegangan moral dan faktor psikologis yang membentuk kerangka berpikir yang benar dalam melandasi tindakan. ${ }^{70}$ Sekalipun landasan otoritatif Al-Qur'an dan sunnah telah banyak menjelaskan bahwa tujuan inti dari Islam adalah penyempurnaan moral, moralitas itu sendiri dijelaskan secara beragam di berbagai diskursus keilmuan dalam Islam.

Dalam Islam, konsep-konsep etika atau lebih sering disebut akhlak, keagamaan dan prilaku individu dan sosial sebenarnya telah terdapat pada teks-teks suci, namun tidak berisi teori-teori etika dalam bentuk baku walaupun ia membentuk keseluruhan etika Islam.71 Perkataan akhlak, adalah bentuk jamak dari kata dari khuluqun yang menurut lughat diartikan budi pekerti, perangai, tingkah laku dan tabiat. Kata tersebut

\footnotetext{
${ }^{66}$ K. Bertens, dalam "Pengantar", Aristoteles, Nicomachean Ethics., p. vii.

${ }^{67}$ Agustinus W. Dewantara, Filsafat Moral., p. 48.

68 Abdul Aziz bin Fathi as-Sayyid Nada, Ensiklopedi Etika Islam: Begini Semestinya Muslim Berperilaku, terj. Muhammad Isnaini dan Dumyati (Jakarta: Maghfirah Pustaka, 2008), p. 16.

${ }^{69}$ Abad Badruzaman, Kesalehan Sosial di Balik Ketaatan Ritual (Jakarta: Elex Media Komputindo, 2017), p. 40.

70 Fazlur Rahman, Islam: Sejarah Pemikiran dan Peradaban, terj. M. Irsyad Rafsadie (Bandung: Mizan, 2017), p. 363.

${ }^{71}$ Muhammad Taufik, 'Etika Plato dan Aristoteles dalam Perspektif Etika Islam', Jurnal Refleksi, Vol. 18, No. 1 (2018), p. 40.
} 
mengandung segi-segi keterkaitan dengan perkataan khalqun yang berarti kejadian, serta erat hubungannya dengan khaliq yang berarti pencipta, dan makhluk yang berarti diciptakan. Perumusan pengertian akhlak timbul sebagai media yang memungkinkan adanya hubungan baik antara khalik dengan makhluk dan makhluk dengan makhluk.72 Dalam makna demikian ini sebenarnya secara fundamental, Islam telah mengajarkan tatanan moral bagi manusia. Namun sekali lagi ia adalah bagian dari hubungan peribadatan manusia kepada Tuhan. Ia menjadi buah dari keimanan dan ketakwaan kepada Tuhan. Hal yang demikian ini, misalnya, dijelaskan dalam Al-Qur'an:

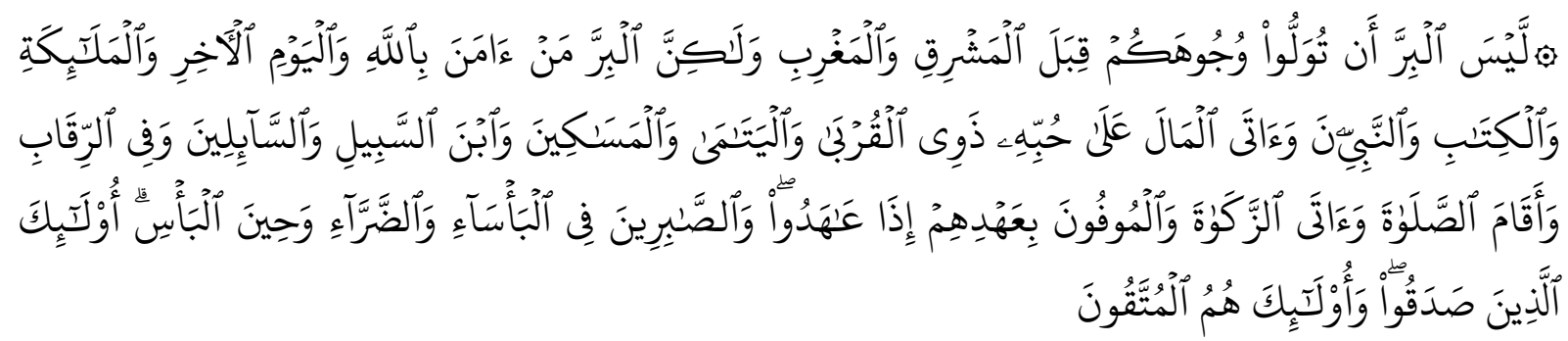

Bukanlah menghadapkan wajahmu ke arah timur dan barat itu suatu kebajikan, akan tetapi Sesungguhnya kebajikan itu ialah beriman kepada Allah, hari Kemudian, malaikat-malaikat, kitab-kitab, nabi-nabi dan memberikan harta yang dicintainya kepada kerabatnya, anak-anak yatim, orang-orang miskin, musafir (yang memerlukan pertolongan) dan orang-orang yang meminta-minta; dan (memerdekakan) hamba sahaya, mendirikan shalat, dan menunaikan zakat; dan orang-orang yang menepati janjinya apabila ia berjanji, dan orang-orang yang sabar dalam kesempitan, penderitaan dan dalam peperangan. mereka Itulah orangorang yang benar (imannya); dan mereka Itulah orang-orang yang bertakwa.73

Dengan kata lain, berbeda dengan etika Aristoteles yang diupayakan melalui kehendak bebas manusia menyerap keutamaan intelektual supaya dapat memilih posisi tengah yang menjadi tempat di mana keutamaan moral bersemayam, dalam Islam etika mula-mula justru bersifat dogmatis sebagai dasar yang absolut. Perbedaan yang terjadi kemudian hanyalah bersifat tafsiran dan pengembangan semata, yang tidak dapat meruntuhkan landasar dogmatis tersebut.

Sekalipun begitu, bidang fisafat dalam Islam adalah diskursus paling banyak mengeksplorasi pemikiran-pemikiran Yunani khususnya Aristoteles dan Plato, dan terlebih lagi pikiran-pikran etika Aristoteles dalam The Nicomachean Ethics. Karya tersebut menjadi salah satu karya yang berhasil diterjemakan ke dalam bahasa Arab oleh

72 Ibid., p. 41.

73 Q.S. Al Baqarah: 177. 
Hunayn bin Ishaq yang terkenal dengan kitab Niqumakhiyah. Dari sinilah kemudian teksteks etika muncul dalam dunia filsafat Islam, terutama melalui pikiran filsuf awal seperti al-Kindi dan al-Farabi. Al-Farabi bahkan berhasil menjadi salah satu komentator bagi pikiran-pikiran etika Aristoteles tersebut. ${ }^{74}$ Ia menjelaskan bahwa secara umum, terdapat dua pandangan tentang kebahagiaan manusia yang terlihat berbeda, yaitu: Pertama, yang bersifat teoretis yang dipaparkan dalam karyanya al-Madinah al-Fadhilah (On the Perfect State) dan al-Siyasah al-Madaniyyah (The Political Regime). Kedua, yang mengadopsi bentuk pemikiran Plato dalam bidang filsafat dan politik yang termaktub dalam Tahshîl al-Sa'âdah (The Attainment of Happiness). Pandangan pertamalah yang menegaskan bahwa kebahagiaan manusia dapat diidentifikasi melalui aktifitas yang dilakukan oleh jiwa yang terpisah dari badan. ${ }^{75}$

Kecemerlangan Al-Farabi dalam menjelaskan pandangan-pandangan Aristoteles membuatnya dijuluki sebagai al-mu'alim al-tsani (Guru Kedua), yakni setelah Aristoteles yang dianggap sebagai Guru Pertama. Melalui pemikrian Aristoteles, Al-Farabi kemudian membedakan pengertian antara kenikmatan dan kebahagiaan yang dipahami pada level orang awam dan level di atasnya. Orang awam mendefinisikan kebahagiaan sebagai kenikmatan yang dapat disamakan dengan kesejahteraan. Kebahagiaan dalam tingkatan ini sama dengan kenikmatan. Sementara kebahagiaan yang memiliki tingkatan lebih tinggi adalah kebahagiaan yang bersifat abadi. Kebahagiaan ini merupakan kebahagiaan yang terlepas dari kenikmatan yang bercorak materi atau fisik. ${ }^{76}$ Al-Farabi juga menyepakati pandangan Aristoteles mengenai posisi kebahagiaan dalam diskursus etika. Menurutnya, kebahagiaan adalah kebaikan puncak (absolute good). Kebaikan yang diinginkan untuk kebaikan itu sendiri, tidak ada yang lebih lagi untuk diraih. ${ }^{77}$ Kebahagiaan puncak akan diraih melalui keutamaan, yang sering diartikan sebagai kebajikan (virtue). Untuk mencapai kebahagiaan puncak, manusia harus dapat memadukan antara keutamaan teoretis, berpikir, moral, dan praksis. ${ }^{78}$

74 Muhammad syafi'i, 'Etika dalam Pandangan al-Farabi', Jurnal Ilmu Ushuluddin, vol. 16, no. 2 (2017), p. 145.

75 Ibid., p. 146.

${ }^{76}$ Rusfian Effendi, Filsafat Kebahagiaan., p. 60-61.

77 Ibid., p. 62.

78 Ibid., pp. 69-70. 
Sekalipun para filosof muslim banyak terpengaruh oleh pemikiran Aristoteles, pikiran-pikiran yang dilahirkan justru menjadi semacam landasan filosofis untuk menjelaskan dogma-dogma Islam. Pemikiran etika yang dilahirkan oleh para filosof tidak pernah benar-benar meruntuhkan atau setidaknya menggantikan landasan otoritatif agama. Meskipun pandangan mereka ditentang oleh tokoh-tokoh lain. Bahkan Al-Ghazali, meskipun dalam beberapa hal mengkritik para filosof, ia juga terpengaruh oleh etika Aristoteles dalam banyak hal. Al-Ghazali menjelaskan, bahwa kebahagiaan sejati merupakan puncak kebahagiaan yang murni, sama seperti kebahagiaan sebagai Summum Bonum. Namun Al-Ghazali jusru mengelaborasinya dengan pandangan-pandangan yang bercorak sufistik. Menurutnya, kebahagiaan sejati membawa diri manusia kepada peleburan dengan Tuhan hingga yang terlihat dari sifatnya adalah sifat Tuhan. seseorang yang telah mencapai dan merasakan kebahagiaan sejati tidak akan tertipu dan terjerumus ke dalam hal-hal yang bersifat materi dan kenikmatan sementara atau temporal. Seseorang yang telah menemukan kebahagiaan sejati akan merasakan ketenangan dan ketentraman jiwa. ${ }^{79}$

Pengaruh etika Aristoteles dalam diskursus tasawuf, sebagaimana ditampilkan oleh Al-Ghazali, kemudian menempatkan posisi kebahagiaan dalam kondisi pertemuan dengan Tuhan. kondisi semacam ini oleh banyak sufi dibahasakan dan ditafsirkan secara beragam, namun kondisi demikian ini menjadi penafsiran yang religius terhadap kebahagiaan yang menurut Aristoteles adalah pemenuhan potensi jiwa melalui keutamaan teoretis dan keutamaan praktis. Pertemuan atau penyatuan dengan Tuhan kemudian menjadi gambaran yang lebih konkrit atas kebahagiaan dalam Islam. Sehingga mula-mula, untuk mencapai kondisi tersebut, dasar keimanan adalah satu-satunya kunci yang harus terus ditumbihkan. Seakan-akant tidak ada kebahagiaan tanpa ketenangan, dan tidak ada ketenangan tanpa iman. Ketenangan jiwa, tidak diragukan, merupakan sumber pertama kebahagiaan. ${ }^{80}$ Sehingga, puncak dari kebahagiaan sejati adalah jika seseorang telah ma'rifatullah, karena kebahagiaan sejati dapat dirasakan ketika seseorang sudah dekat dan mengenal Allah. ${ }^{81}$

\footnotetext{
${ }^{79}$ Ibid., p. 46.

${ }^{80}$ Abad Badruzaman, Kesalehan Sosial., p. 9.

${ }^{81}$ Rusfian Effendi, Filsafat Kebahagiaan., p. 47.
} 
Filsafat yang oleh Aristoteles menempati posisi istimewa sebagai bidang keahlian untuk menyempurnakan keutamaan intelektual, oleh Al-Ghazali sebenarnya juga ditempatkan pada posisi yang sama. Hanya saja, bagi Al-Ghazali keahlian berpikir secara teoretis bukan hanya terkandung dalam filsafat, akan tetapi ilmu pengetahuan secara umum. Ia mengatakan, kebahagiaan tergantung pada kesempurnaan jiwa, dan kesempurnaan jiwa tergantung pada pengetahuan. Semakin bertambah pengetahuan seseorang, semakin bertambah pula kesempurnaan jiwa, maka semakin bertambah kebahagiaan. ${ }^{82}$ Semakun seseorang mampu mencapai kesempurnaan pengetahuan, tidak lain ia telah menyempurnakan jiwanya, sehingga secara tidak langsung mampu menapaki jejak-jekak pendakian menuju pengetahuan Tuhan sebagai jalan untuk mencapai kebahagiaan. Muhammad Abdullah Daraz juga mengatakan, sebagaimana dikutip oleh Badruzaman, bahwa keliru jika kita menyangka ilmu pengetahuan saja zanggup menjamin terciptanya kedamaian dan ketenangan. Tidak benar jika ilmu pengetahuan dapat menggantikan pendidikan serta tuntunan agama dan akhlak. Itu tak lain karena ilmu bagaikan pisau bermata dua, dapat merusak dan menghancurkan, seperti juga dapat membangun dan menyejahterakan. Agar kita dapat menggunakannya dengan baik maka harus ada pengawas moral yang mengarahkannya pada hal-hal yang melahirkan kebaikan bagi manusia dan kemakmuran bumi, bukan kepada keburukan dan kerusakan. Pengawas itu adalah akidah dan iman. ${ }^{83}$

Terlepas dari berbagai pandangan tentang konsepsi etika atau moralitas dalam Islam, secara umum umat Islam menyadari bahwa agama mereka tidak sekedar mengajak dan memuji akhlak mulia. Lebih dari itu, agama membangun kaidah-kaidahnya, menentukan batas-batasnya, menetapkan tolok ukurnya, memberi sejumlah contoh bagi beberapa perilaku, mendorong manusia untuk konsisten memedomaninya, mewantiwanti mereka agar tidak melakukan penyimpangan, serta menetapkan reward dan punishment; reward bagi perilaku terpuji, punishment bagi perilaku tercela. ${ }^{84}$ Dalam bingkai peribadatan inilah etika dalam Islam memiliki nilai dihadapan Tuhan. Bahkan, sebagaimana terdapat dalam Aristoteles, bahwa kebajikan, keutamaan, atau kebaikan dalam Islam juga bukan semata-mata spiritual, tapi juga material. Dalam Al-Qur'an telah

\footnotetext{
82 Ibid., pp. 72-3.

83 Abad Badruzaman, Kesalehan Sosial., p. 39.

84 Ibid., p. 40.
} 
banyak menyinggung tentang keseimbangan antara keduanya, yaitu akhirat yang bersifat spiritual dan dunia material. Demikian hanya dengan kenikmatan metrial bagi Aristoteles, di mana ia bukanlah tujuan inti dari tindakan manusia namun tetap dianggap penting, AlQur'an juga banyak mengeksplorasi kenikmatan-kenikmatan dengan gambaran materia sebagai balasan kebaikan bagi manusia.

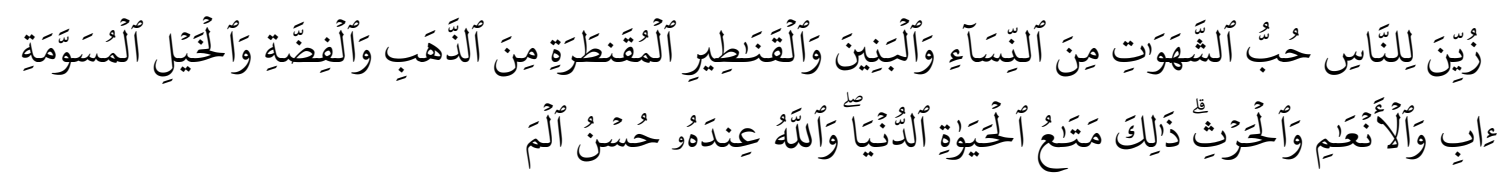

Dijadikan indah pada (pandangan) manusia kecintaan kepada apa-apa yang diingini, Yaitu: wanita-wanita, anak-anak, harta yang banyak dari jenis emas, perak, kuda pilihan, binatang-binatang ternak dan sawah ladang. Itulah kesenangan hidup di dunia, dan di sisi Allah-lah tempat kembali yang baik.85

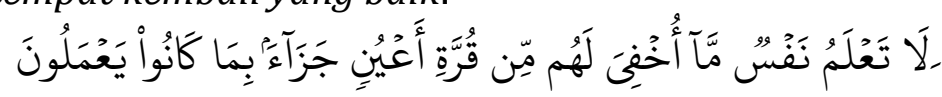

Tak seorangpun mengetahui berbagai nikmatyang menanti, yang indah dipandang sebagai Balasan bagi mereka, atas apa yang mereka kerjakan. ${ }^{86}$

Sehingga penggambaran kebahagiaan dalam Islam, sebagaimana ditunjukkan dalam Al-Qur'an, dengan penggambaran kebahagiaan Aristoteles, juga memandang perlunya jalan tengah di antara dua pilihan. Jika Aristoteles menempatkan pilihan tersebut di antara kelebihan dan kekurangan, maka Islam menempatkan pililhan tersebut antara dunia dan akhirat. Al-Qur'an menjalaskan:

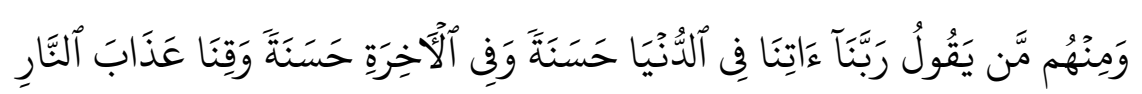

Dan di antara mereka ada orang yang bendoa: "Ya Tuhan Kami, berilah Kami kebaikan di dunia dan kebaikan di akhirat dan peliharalah Kami dari siksa neraka. ${ }^{87}$

Namun perbedaannya adalah, sebagaimana ditunjukkan dalam ayat tersebut, bahwa dalam Islam, dunia dan akhirat memiliki posisi yang sama yang harus diseimbangkan, akan tetapi bagi Aristoteles antara kelebihan dan kekurangan seakanakan mengandaikan satu posisi tengah yang dapat diambil tanpa menyentuh kelebihan dan kekurangan tersebut.

85 Q.S. Ali Imran: 14.

${ }^{86}$ Q.S. As Sajadah: 17.

87 Q.S. Al Baqarah: 201. 


\section{F. PENUTUP}

The Nicomachean Ethics adalah karya filsafat Aristoteles yang membahas mengenai etika atau moral. Ia bisa dianggap sebagai karya filsafat etika yang memiliki pengaruh paling luas dan bertahan dalam waktu yang lama. Bahkan hingga kini, banyak pikiran-pikiran Aristoteles dalam karya tersebut yang masih dapat ditafsirkan dan diterapkan di era sekarang. Dalam karya tersebut, Aristoteles mengandaikan satu bentuk kesempurnaan moral manusia secara umum, di mana kebahagiaan menjadi tujuan puncaknya dan tidak ada lagi tujuan selainnya. Ia mengandaikan sebuah struktur moral yang dapat mengantarkan manusia menuju kebahagiaan, yaitu dengan menetapkan posisi tengah sebagai suatu yang harus dipilih dan dipertimbangan dalam setiap tindakan. Tidak hanya secara individu, struktur moral ini juga mesti dibangun dalam ruang politik dan kehidupan sosial sehari-hari, seperti dalam persahabatan. Jalan tengah harus diambil dan diupayakan mulai dari tindakan seharai-hari hingga dalam pembentukan dasar-dasar hukum sosial politik. Etika Aristoteles yang menurut beberapa peneliti dianggap bersifat teologis juga di satu sisi dapat dibenarkan, dalam batasan bahwa ia muncul dalam jiwa yang dipenuhi kebajikan, bukan dalam makna bahwa ia dilandasi dogma-dogma keagamaan.

Dalam Islam, etika Aristoteles ini jelas memiliki pengaruh yang sangat signifikan, khususnya bagi para filosof dan kalangan sufi. Pikiran-pikirannya diterjemahkan ke dalam nuansa Islam dan digunakan sebagai penjelasan yang filosofis terhadap dogmadogma Islam. Mereka juga menyepakati bahwa kebahagiaan adalah tujuan puncak manusia. Namun diartikan sebagai tujuan untuk bertemu atau melebur dalam Tuhan. Sekalipun begitu, terlepas dari pengaruh The Nicomachean Ethics bagi para pemikir muslim, dalam Islam sendiri telah diatur dan dijelaskan mengenai konsepsi moral yang sangat religius. Umumnya konsepsi tersebut diturunkan dari hubungan antara Tuhan dan manusia, sehingga etika atau moral dalam Islam lebih bernilai ibadah. Aturan dan batasan untuk memilih posisi tengah yang utama, yang bagi Aristoteles harus lahir dari kehendak bebas manusia, dalam Islam diturunkan dari dogma wahyu Tuhan. Sehingga keutamaan moral dalam Islam menjadi hasil dari keimanan. Begitu juga keseimbangan dalam posisi tengah dalam Islam juga menyangkut kehidupan manusia baik di dunia maupun di akhirat. 


\section{DAFTAR PUSTAKA}

Badruzaman, Abad. Kesalehan Sosial di Balik Ketaminaatan Ritual. Jakarta: Elex Media Komputindo, 2017.

Nada, Abdul Aziz bin Fathi as-Sayyid. Ensiklopedi Etika Islam: Begini Semestinya Muslim Berperilaku. Terj. Muhammad Isnaini dan Dumyati. Jakarta: Maghfirah Pustaka, 2008.

Razak, Abdul. Filsafat Etika Islam. Bandung: Pustaka Setia, 2011.

Dewantara, Agustinus W. Filsafat Moral. Yogyakarta: Kanisius, 2017.

Abdullah, Amin. Falsafah Kalam di Era Postmodernisme. Yogyakarta: Pustaka Pelajar, 2009.

Aristoteles. Nicomachean Ethics: Sebuah "Kitab Suci" Etika. Terj. Embun Kenyowati. Jakarta: Teraju, 2004.

Bartlett, Robert C. dan Collins, Susan D. Aristotle's Nicomachean Ethics. Chicago: The University of Chicago Press, 2011.

Bertens, K. Ringkasan Sejarah Filsafat. Yogyakarta: Kanisius, 2012.

Suseno, Faranz Magnis. 13 Tokoh Etika sejak Zaman Yunani sampai Abad ke-19. Yogyakarta: Kanisius, 2015.

Rahman, Fazlur. Islam: Sejarah Pemikiran dan Peradaban. Terj. M. Irsyad Rafsadie. Bandung: Mizan, 2017.

Suseno, Franz Magnis. Menjadi Manusia Belajar Dari Aristoteles. Yogyakarta, Kanisius: 2009.

Betens, K. Ringkasan Sejarah Filsafat. Yogyakarta: Kanisius, 2011.

Rahman, Masykur Arif. Buku Pintar Sejarah Filsafat Barat. Yogyakarta, IRCISOD, 2013.

Alfan, Muhammad. Filsafat Etika Islam. Bandung: Pustaka Setia, 2011.

Syafi'i, Muhammad. 'Etika dalam pandangan al-farabi', Jurnal Ilmu Ushuluddin, vol. 16, no. 2 (2017). PP. 139-160. (https://dx.doi.org/10.18592/jiu.v16i2.1522)

Taufik, Muhammad. 'Etika Plato dan Aristoteles dalam Perspektif Etika Islam', Refleksi, Vol. 18, No. 1 (2018). (https://doi.org/10.14421/ref.2018.\%25x)

Edwards, Paul (ed.). The Encyclopedia of Philosophy, Vol. I-II. New York: Macmillan Publishing, 1967.

Bartlett, Robert C., dan Susan D. Collins. Aristotle's Nicomachean Ethics. Chicago: The University of Chichago Press. 2011.

Hutchins, Robert Maynard (ed.). Great Books of the Western World, Vol. VII. USA: University of Chicago Press, 1989.

Effendi, Rusfian. Filsafat Kebahagiaan. Yogyakarta: Penerbit Deepublish, 2017.

Blackburn, Simon. Kamus Filsafat. edisi ke-2. Terj. Yudi Santoso. Yogyakarta: Pustaka Pelajar, 2013.

Tim Penyusun Kamus Pusat Pembinaan dan Pengembangan Bahasa. Kamus Besar Bahasa Indonesia, Cet. ke-2. Jakarta: Balai Pustaka, 1989. 